\title{
The Effect of Surface Pre-Treatment and PVD Coating Post-Treatment on Texture of Surface ASP2052®/Tin
}

Ondřej Klanica, Emil Svoboda, Karel Maňas

Faculty of Military Technology, Univerzita obrany. Kounicova 65, 66210 Brno. Czech Republic. E-mail:ondrej.klanica@unob.cz,emil.svoboda@unob.cz,karel.manas@unob.cz.

The aim of the paper is analyse changes of the surface texture during pre-treatment, PVD coating and post-treatment. Generally, the effect of the production technology is often discussed with well-known parameters such as material, geometry of tools, coating methods and conditions. Effect treatment of the substrate or tools manufacturing are mostly ignored. Pre-treatment, coating and post-treatment obviously change surface texture. Quality of surface or surface texture together with properties of the surface layer have a significant effect of lifetime and reliability of operation component in practice. Surface texture effect running accuracy components, noise and running in period, friction loss, heat transfer, fatigue strength, resistance against wear and corrosion. The experiment was performed on ASP2052 ${ }^{\circledR}$ tool steels during coating by PVD (Physical Vapour Deposition). The surface of the substrate was wet and dry sandblasted. Treated surface of experimental samples were coating of TiN. After coating surface of the samples was polished by and wet sandblasted to achieve glossy finished. The results of the paper show effect various type of the treatment on surface texture before and after PVD coating. Measurement of the surface texture shows progression of the parameters surface textures.

Keywords: Polishing, Sandblasting, Quality of surface, Measurement of surface texture.

\section{Acknowledgement}

The paper was prepared with the support of the Project for the Development of the Organization and by the Specific research project 2017 of the Department of Mechanical Engineering, UoD "Promoting Research, Science and Innovation in the Field of Engineering".

\section{References}

[1] PISA, M. (2014). Trendy PVD a CVD povlakování. In: MM Prümyslové Spektrum, p. 70. ISSN 1212-2572.

[2] JAROS, A., FIALA, Z. (2016). Investigation of the Influence of PVD Coatings Deposited on HSS Milling Cutter. In: Manufacturing Technology, Vol. 16, pp. 506-512. ISSN 1213-2489.

[3] HANES, T., HVIZDOS, P., TAVOdOVÁ, M., KALINCOVA, D., HRICOVA, J., BENO, P. (2014). Coating Surface Roughness Measurement Made On Coining Dies. In: Manufacturing Technology, Vol. 14, pp. 309-317. ISSN 1213-2489.

[4] NOVAK, Z. (2009). Prostorová charakteristika textury povrchu. In: MM Průmyslové Spektrum, p. 64. ISSN 12122572.

[5] STANKOVIC, S., RAKOCEVIC, Z., MARINKOVIC, S. (1999). Effects of the pretreatment of a cemented carbide surface on its properties and on the properties of diamond coatings deposited by oxygen-acetylene flame CVD. In: Diamond and Related Materials. p. 207-210. ISSN 0925-9635.

[6] PODGORNIK, B., HOGMARK, S., SANDBERG, O.(2000). Influence of surface roughness and coating type on the galling properties of coated forming tool steel. In: Surface and Coatings Technology, pp. 338-348. ISSN 02578972.

[7] JIANG, J., ARNELL, R.,D. (2000). The effect of substrate surface roughness on the wear of DLC coatings. In: Wear, pp. 1-9. ISSN 0043-1648.

[8] RIEDL, A., SCHALK, N., CZETTL., C., SARTORY, B.,MITTERER, C. (2012). Tribological properties of $\mathrm{Al}_{2} \mathrm{O}_{3}$ hard coatings modified by mechanical blasting and polishing post-treatment. In: Wear, pp. 9-16. ISSN 0043-1648.

[9] ADOBERG, E., PODGURSKI, V., PEETSALU, P., LIND, L., MIKLI, V., HVIZDOSC, P., KULUA, P. (2012). The effect of surface pre-treatment and coating post-treatment to the properties of TiN coatings. In: Estonian Journal of Engineering, pp. 185-192. ISSN 1406-0175.

[10] KLANICA, O., DOBROCKÝ, D., SVOBODA, E.; SONDOR, J. (2014). Influence of the high speed part polishing coating tools on the changes surface texture. In: METAL 2014, 23rd International Conference on Metallurgy and Materials. ISBN 978-80-872-4-52-9. 
[11] KLANICA, O., SVOBODA, E., JOSKA, Z. (2015). Changes of the Surface Texture after Surface Treatment HS6-5-2-5 Steel. In: Manufacturing Technology, Vol. 15, pp. 47-57. ISSN 1213-2489.

[12] Erasteel - ASP 2052 Steel (HS 10-2-5-8, PM52) - [online]. [cit. 2016-06-14]. Web: http://www.erasteel.com/sites/default/files/media/document/GB_Grade_ASP2052_0.pdf

[13] CSN EN ISO 25178-2. Geometrické požadavky na výrobky (GPS) - Textura povrchu: Plocha - Část 2: Termíny, definice a parametry textury povrchu. Česká technická norma, Český normalizační institut, 2012.

[14] CSN EN ISO 4287. Geometrické požadavky na výrobky (GPS) - Struktura povrchu: Profilová metoda - Termíny, definice a parametry struktury povrchu. Česká technická norma, Český normalizační institut, 1998.

[15] Talysurf CCI - Lite Non-contact 3D Profiler: Manual. 2008. Web: http://www.zimmerman.com.tw/uploads/talysurf-cci-lite.pdf.

[16] NOVAK, Z. (2011). Zvýšení kvality hodnocení textury povrchu. In: MM Průmyslové Spektrum, p. 52. ISSN 12122572. 